\title{
Determinants of Economic Growth in South Sumatra in 2010 - 2018
}

\author{
Sri Hartaty ${ }^{1, *}$ Eka Jumarni $\mathrm{F}^{1}$ Anggeraini $\mathrm{O}^{1}$ L. Vera R.P $\mathrm{P}^{1}$ \\ ${ }^{1}$ Accounting Department, Politeknik Negeri Sriwijaya, Indonesia \\ *Corresponding author. Email: atik.hasyim@gmail.com
}

\begin{abstract}
This study empirically examines the effect of government expenditures, government investments and private investments on economic growth in regional goverments (regencies and cities) in the South Sumatra Province (Sumsel) from 2010 to 2018. Out of a population of 17 regencies and cities in South Sumatra, there are 2 regencies that do not became the research sample, because the division of Pali and Muratara regencies was carried out in 2013. The results showed that government expenditures and private investments had positively affected the economic growth. However, government investments did not affect the economic growth in regencies and cities in the province of South Sumatra.
\end{abstract}

Keywords: Goverment, Expenditure, Investment, Sumsel, Regencies.

\section{INTRODUCTION}

Sustainable economic growth can improve people's welfare because economic growth is an indicator to measure the increase in a country's development. In essence, economic development is a process of continuous improvement of a society or the entire social order towards a better life, where the development process aims to improve the people's welfare and human dignity, including the improvement of various needs, improve living standards and expand economic and social options for communities.

\subsection{Background}

The government is obliged to contribute to improving the economy in general, the government which plays a role in controlling and helping the economy. However, in this case, the task of increasing the level of welfare is not only the obligation of the government but also of all components of society. For this reason, the government must encourage and empower all components of society, including the private sector, to play a bigger role in improving people's welfare. So, economic conditions are higher, fairer, and more equitable can be achieved better and faster.

The economic development of a country can be measured by economic growth, which shows the growth of goods and services in an economic area within a certain period. This product is measured in terms of added value created by economic sectors in the region which are known in total as Gross Domestic Product (GDP). So, GDP can be used as an indicator to measure the economic performance of a country or as a government building in driving economic sectors. GDP is presented in two price concepts that are shared prices and constant prices.

The role of the government in terms of economic development can also be studied from the National Revenue and Expenditure Budget (APBN) at the central government level and the Regional Revenue and Expenditure Budget (APBD) at the regional government level. The APBN and APBD structures are divided into revenue and expenditure sides. Government expenditure on major activities in accelerating the economy where this economy is running well will certainly open more job opportunities or business opportunities in the economy.

In addition to government expenditure, another important instrument to drive the economy is investment. According to Hartono (2013), investment is the cessation of the current consumption of productive assets for a specified period. The next form of private investment in domestic investment (PMDN). Rostow (2017) argues that a country's economic growth must rely on domestic capabilities, while external resources should only stimulate and assist internal forces. According to Handayani (2014), the relationship 
between investment, that are PMA and PMDN with economic growth is the existence of investment in the form of purchasing of capital goods and completeness of production to raise the ability in producing goods and services needed in the economy so that this can increase Indonesia's real GDP. So, it will have a positive effect on economic growth. Meanwhile, Sutawijaya (2010) states that increased investment will increase production capacity which in turn will lead to the opening of new job opportunities, which in the next stage will encourage economic growth. The Central Bureau of Statistics (BPS) noted that in 2014 the realization of foreign investment was IDR 354.91 trillion and increased to IDR 403.86 trillion in 2015. Meanwhile, PMDN in 2014 amounted to IDR 156.13 trillion and in 2015 it increased to IDR 179.47 trillion. In 2016, the realization of investment, both PMDN, and PMA, amounted to Rp. 612.8 trillion or exceeded the 2016 investment target of $3 \%$ of the target figure of Rp. 594 trillion. A positive trend occurred again in 2017, the realization of investment, both PMDN, and PMA, was the highest investment realization since 2014, which reached Rp.692.8 trillion, exceeding the target of 2017 PMDN and PMA investment realization of Rp. 678.8 trillion. The increase in investment realization in 2015 did not have an impact on overall economic growth. The Central Statistics Agency (BPS) recorded economic growth figures. In 2015, it experienced a slowdown to $4.79 \%$ from the previous year which was $5.02 \%$. The slowdown in the growth rate in 2015 according to Suryamin (2015) was due to a slowdown in both the production and consumption sides. The slowdown in economic growth from the production side was due to the late realization of infrastructure expenditure. Meanwhile, from the expenditure side, there are several causes, one of them is the low expenditure component and slower consumption expenditure. The purpose of this study is to empirically examine the effect of government expenditures, government investments and private investments which are factors that could affect the economic growth in South Sumatra.

\subsection{Main Problem}

Based on the background above, this study will discuss the following problems:

1. Do government expenditures affect the economic growth of regencies and cities in South Sumatra?

2. Do government investments affect the economic growth of regencies and cities in South Sumatra?

3. Do private investments affect the economic growth of regencies and cities in South Sumatra?

4. Do government expenditures, government investments and private investmenst affect the economic growth of regencies and cities in South Sumatra?

\section{LITERATURE REVIEW}

For regional governments, based on Government Regulation Number 58 of 2005 which is later elaborated in Permendagri Number 13 of 2006, expenditures are classified by type of expenditures as indirect expenditures and direct expenditures. The indirect expenditures are budgeted expenditures not directly related to the programs and the activities. The direct expenditures are the budgeted expenditures directly related to the programs and the activities.

There are many things that the government must consider in making decisions about expenditures. The government should not only achieve the ultimate goal of each of its spending policies, but also have to consider the intermediate targets who will enjoy or be affected by the policy. If the government has established a policy for purchasing goods and services, then government spending reflects the costs that must be incurred by the government to implement the policy.

Government expenditure according to Sukirno (2011) in the Government Expenditure Development model by Rostow and Musgrave, is an early stage of economic development, the percentage of government investment to total investment is large because at this stage the government must provide infrastructures such as education, health, transportation infrastructures and so on.

In the middle stage of economic development, government investment is still needed to increase economic growth so that it can take off, but at this stage the role of private investment is getting bigger. The role of the government is still great in the medium stage, because this growing role of the private sector causes many market failures, and also causes the government to provide public goods and services in large quantities and better quality. In addition, at this stage, economic development causes inter-sectoral relations to become increasingly complex.

Investments made by the private sector are aimed at seeking profit and earning income and are driven by the motive of increasing income. If income increases, consumption will increase and effective demand will also increase. Investments arise as a result of increased demand, whose source lies in increasing income, called induced investment. In developed countries such as the United States, foreign capital, especially from Japan and Western Europe, is still needed to spur domestic economic growth and avoid market sluggishness and the creation of job opportunities. Especially in developing countries such as Indonesia, foreign capital is needed, especially to meet the lack of domestic capital. For this reason, various policies in the investment sector need to be created in an effort to attract private, both foreign and domestic parties to invest in Indonesia. According to Kuznets (2010), economic growth is an increase in the long-term capacity of a country to provide various economic goods to its population. The increasing 
capacity is made possible due to advances or adjustments in technology, institutional and ideology to various existing conditions. Economic development has a broader meaning and includes changes in the overall economic structure of society. In general, economic growth is an increase in the ability of an economy to produce goods and services. Economic growth is one of the most important indicators in analyzing the economic development of a country.

\section{RESEARCH MTHODOLOGY}

This study used quantitative method. The population of the study were all cities and regency in South Sumatra province. However, only 4 cities and 11 regencies were sampled because Pali and Muratara regency were new regency that were founded in 2013. The empirical data analysis technique used multiple regression with equations;

$$
\mathrm{Y}=\mathrm{a}+\mathrm{b}_{1} \mathrm{X}_{1}+\mathrm{b}_{2} \mathrm{X}_{2}+\mathrm{b}_{3} \mathrm{X}_{3}+\mathrm{e}
$$

\section{RESULTS AND DISCUSSION}

The results of multiple regression analysis are as follows:

\begin{tabular}{|c|c|c|c|c|}
\hline Model & $\mathrm{R}$ & $\begin{array}{c}\mathrm{R} \\
\text { Square } \\
\end{array}$ & $\begin{array}{c}\text { Adjusted R } \\
\text { Square } \\
\end{array}$ & $\begin{array}{c}\text { Std. Error of the } \\
\text { Estimate }\end{array}$ \\
\hline 1 & $.726^{a}$ & .527 & .509 & 2676.4098 \\
\hline
\end{tabular}

a. Predictors: (Constant), X3, X2, X1

Based on Table $4.1, \mathrm{R} 2$ is $52.7 \%$. That means the variation of the independent variables is able to explain the dependent variable by $52.7 \%$, while the rest is explained by other factors outside the study.

Next are the results of the F test:

Table 4.2 ANOVA A $^{a}$

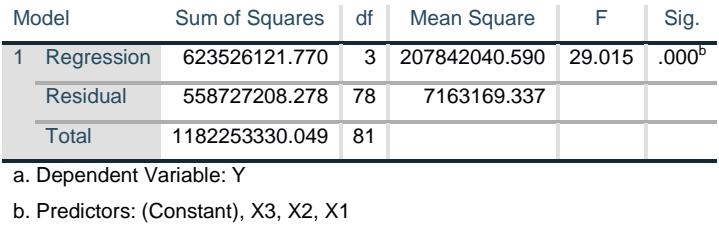

Based on table 4.2, the independent variables jointly affect the dependent variable. table:

The partial test results are shown in the following

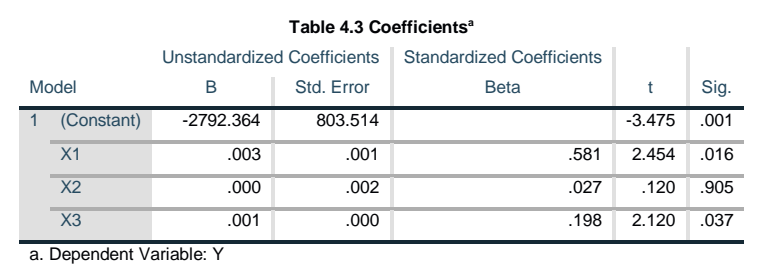

Based on the test results, the equation is obtained:

$$
\mathrm{Y}=-2792,364+0,581 \mathrm{X} 1+0,027 \mathrm{X} 2+0,198 \mathrm{X} 3+\mathrm{e} .
$$

Based on table 4.3 , the government expenditure and private investment both affect the economic growth. It means that the increase in expenditure and private investment is in line with economic growth.

Government investment has no effect. One of the reasons that government investment does not affect to the economic growth is the investment in the form of capital expenditures is already contained in government expenditure. Investments in the form of portfolios cannot be enjoyed directly by the community.

In general, the highest economic growth in regency and cities in South Sumatra occurred in 2014. Economic growth in Ogan Komering Ilir (OKI) regency was $91 \%$. The lowest economic growth occurred in 2013 in Musi Rawas Regency, namely $-17 \%$ and Muara Enim by 8\%. In 2013, in Musi Rawas regency was divided into Musi Rawas and Musi Rawas Utara regency. Muara Enim Regency also experienced a division into Muara Enim and Penukal Abab Lematang Ilir regency.

Private investment is not intended for all regencies and cities in South Sumatra. Regency and city that receive continuous private investment are OKI, Muara Enim Regency and Palembang City.

\section{RESEARCH CONTRIBUTION}

The contribution of researchers to this research is the result of data analysis which can be concluded that government investment has no effect on economic growth, because investment in the form of capital expenditure is already contained in government expenditure. Investments in the form of portfolios cannot be enjoyed directly by the community.

\section{ACKNOWLEDGMENTS}

Many parties contributed to this research. Researchers would like to thank the assignment research program developed by the head of Politeknik Negeri Sriwijaya and its staff, as well as the P3M unit as the task force unit. The random division of groups by the accounting department can improve the academic atmosphere in the department. Thanks to the research team for their support too.

\section{REFERENCES}

[1] Handayani, Meitri., Yulia Efni, dan Ahmad Fauzan Fathoni. 2014. Pengaruh Keputusan Investasi dan Keputusan Pendanaan yang Dimediasi Oleh Risiko Terhadap Nilai Perusahaan (Studi Pada Perusahaan Manufaktur Sektor Aneka Industri Periode 2008-2012). Dalam JOM FEKON $\begin{array}{llll}\text { VOL. } & 1 & \text { NO. }\end{array}$ 
OKTOBER 2014, Tahun 2014, Halaman 1-15. Pekanbaru : Universitas Riau

[2] Hartono, Jogiyanto. 2013. Teori Portofolio dan Analisis Investasi. Edisi Kedelapan. Yogyakarta: BPFE.

[3] Kuznets, Simon. 1955. Economic Growth and Income Inequality. The American Economic Review. Vol. 45. No. 1. Pp 1-28

[4] Peraturan Menteri Dalam Negeri Nomor 13 tahun 2006 tentang Pedoman Pengelolaan Keuangan Daerah Nomor 52 tahun 2012 tentang Pedoman Pengelolaan Investasi Pemerintah Daerah.

[6] Nomor 64 tahun 2013 tentang Penerapan Standar Akuntansi Pemerintahan Berbasis Akrual Pada Pemerintah Daerah

[7] Peraturan Pemerintah Nomor 01 tahun 2008 tentang Investasi Pemerintah.

[8]

Nomor 71 tahun 2010 tentang Standar Akuntansi Pemerintahan.
[9] Rostow, W.W. 2017. The Stage of Economic Growth: A Non-Communist Manifesto. Martino Fine Books. Reprints of 1960 First Edition.

[10] Sukirno, Sadono. 2016. Makroekonomi: Teori Pengantar. Jakarta : PT. Raja Grafindo Persada.

[11] Suryamin, 2016. Laporan Perekonomian Indonesia 2016. Badan Pusat Statistik. CV. Nario Sari. Jakarta.

[12] Sutawijaya, Adrian. 2010. "Pengaruh Ekspor dan Investasi Terhadap Pertumbuhan Ekonomi Indonesia Tahun 1980-2006". Jurnal Organisasi dan Manajemen, Vol.6, No.1.

[13] Undang-Undang Nomor 17 tahun 2003 tentang Keuangan Negara. Undang-Undang Nomor 25 Tahun 2007 tentang Penanaman modal

[14] www.bps.go.id diakses pada tanggal 20 Maret 2019 